\title{
NOTES
}

\section{VALIDITY OF FEDERAL INDICTMENTS AND WARRANTS BASED ON HEARSAY EVIDENCE*}

To PROTECT the individual from unreasonable prosecution, federal criminal law requires the government to establish probable cause for believing an accused is guilty before he may be brought to trial. ${ }^{1}$ This determination is made by federal commissioners ${ }^{2}$ and grand juries ${ }^{3}$ in preliminary proceedings which comprise two methods of initiating prosecutions.4 One system employs grand jury indictment followed by arrest. ${ }^{5}$ The other includes a hearing before a commissioner for issuance of warrants, ${ }^{6}$ a further hearing after arrest, ${ }^{7}$ and then grand jury indictment unless waived. ${ }^{8}$ Evidence required to establish

*United States v. Costello, 221 F.2d 668 (2d Cir.), ccrt. granted, 350 U.S. $\$ 19$ (1955).

1. FED. R. CRIM. P. 3-9. The Rules are largely a codification of the practice for initiating prosecution which existed at the time of their adoption. They do, however, change the previous requirement that United States commissioners conform their procedure to that of committing magistrates in the state of an accused's arrest. Federal Rules of CRIMINaL Procedure, 6 N.Y.U. Law School Inst. Proc. 127 (1946) (hereinafter cited as ProceedINGS).

Probable cause has been defined as "reasonable ground for belief of guilt." Carroll v. United States, 267 U.S. 132, 161 (1925) ; Brinegar v. United States, 338 U.S. 160, 175 (1949). See Stacey v. Emery, 97 U.S. 642, 645 (1878) ("circumstances [which] warrant a man of prudence and caution in believing that the offense has been committed").

2. Fen. R. CRIM. P. 5(c).

3. See, e.g., Beavers v. Henkel, 194 U.S. 73, 84 (1904) ; Charge to the Grand Jury, 9 F.R.D. 649, 650 (1950) ; id., 4 F.R.D. 144, 148 (1939) ; Proceedings 178. For a recent discussion of the over-all operation of federal grand juries and indictment procedure, see Desston, Crmitnal Law, Administration and Public Order 857-63 (1948).

4. See, generally, National Conmission on Law Observance and Enforcenent, Report on Criminal Procedure 16-17 (1931).

Federal criminal law also provides a third method of initiating prosecution-by information without prior grand jury or commissioner's proceedings. But this procedure may be used only for offenses not punishable by hard labor or imprisonment for more than one year. FED. R. CRIM. P.7(a).

5. Id. 6-9; United States v. Simon, 248 Fed. 980 (D. Pa. 1916); United States v. Kilpatrick, 16 Fed. 765 (W.D.N.C. 1883).

Since the purpose of proceedings before a commissioner is to determine whether there is sufficient evidence to hold an accused for grand jury action, they are unnecessary if prosecution is initiated by indictment. E.g., United States ex rcl. Kassin v. Mulligan, 295 U.S. 396, 400 (1935) ; Barber v. United States, 142 F.2d 805 (4th Cir. 1944). See also Beavers v. Henkel, 194 U.S. 73, 84-85 (1904); United States e.r rel. Bogish v. Tees, 211 F.2d 69, 72 (3d Cir. 1954).

6. FED. R. CRIN. P. 3, 4, 41.

7. Id. 5. Preliminary hearing follows whether arrest is with or without warrant.

8. Id.6,7.

Waiver of indictment by an accused in open court allows prosecution by information. 
probable cause at these proceedings need not conform to trial standards. ${ }^{9}$ Instead the federal courts have held that at the grand jury the government need produce only some evidence which would be competent at trial. ${ }^{10}$ At commissioner's proceedings a lesser standard applies which permits finding probable cause in the absence of competent evidence if there is some evidence from an eyewitness, even though his testimony would be incompetent at trial.11 Controversy has arisen over the application of these rules to hearsay evidence.

Id. 7(a), (b). Provision for waiver permits an accused unable to furnish bail to avoid being held in jail for an extended period while awaiting grand jury action. Proceedings 16. See also Potts, Waiver of Indictment in Felony Cases, 3 Sw. L.J. 437 (1949).

9. Brinegar v. United States, 338 U.S. 160, 175 (1949) (arrest without warrant); Schroder v. United States, 53 F.2d 6 (5th Cir. 1931) (search warrant); McKinney v. United States, 199 Fed. 25, 28 (8th Cir. 1912) (grand jury). See also 1. Wigmore, Enidence 19 (3d ed. 1940) (hereinafter cited as WigMore). Contra, Grau v. United States, 287 U.S. 124, 128 (1932) (dictum) : "A search warrant may issue only upon evidence which would be competent in the trial of the offense before a jury." Accord, Worthington v. United States, 166 F.2d 557, 564-65 (6th Cir. 1948) (arrest without warrant); United States v. Kilpatrick, 16 Fed. 765, 771-72 (W.D.N.C. 1883) (grand jury). See also MANuAL For United STATES CoMArIssioners 10 (1948).

Grau v. United States, supra, was apparently rejected by the Supreme Court in the Brinegar case, the Court noting that the Grau dictum "has not been repeated by this court." Brinegar v. United States, supra, at 174 n.13. Later cases have disregarded Grau. See, e.g., United States v. Bianco, 189 F.2d 716, 721 (3d Cir. 1951); Seymour v. United States, 177 F.2d 732 (D.C. Cir. 1949). See also Note, 46 Harv. L. Rev. 1307, 1310-11 (1933).

10. E.g., Holt v. United States, 218 U.S. 245, 248 (1910) ; Cox v. Vaught, 52 F.2d 562, 564 (10th Cir. 1931) ; Murdick v. United States, 15 F.2d 965, 967 (8th Cir. 1926), cert. denied sub nom. Clarey v. United States, 274 U.S. 752 (1927); Chadwick v. United States, 141 Fed. 225, 235 (6th Cir. 1905). See 1 Wigmore 21-24 \& n.7; Orfield, Criminal Procedure rrom Arrest to Appeal 162-64 (1947) ; Note, 62 Harv. L. Rev. 111, 113 (1948).

In charging grand jurors, however, some judges have announced a more strict rule, stating that the grand jury should indict only on competent or legal evidence. See, e.g., Charge to the Grand Jury, 9 F.R.D. 649, 650 (1950); id., 4 F.R.D. 243, 248 (1945). But cf. Kaufman, The Grand Jury-Its Role and Its Powers, 17 F.R.D. 331, 335 (1955) (stating the requirement to be "credible evidence").

11. Brinegar v. United States, 338 U.S. 160, 172-74 (1949) (officer's personal knowledge of previous arrest for same offense); Husty v. United States 282 U.S. 694, 701 (1931) (officer's personal knowledge of prior illegal activities). But absent any personal knowledge, findings of probable cause on hearsay alone have been held invalid. E.g., Wrightson v. United States, 222 F.2d 556, 558 n.3 (D.C. Cir. 1955) ; United States v. Kennedy, 5 F.R.D. 310, 312 (D. Colo. 1946) ; United States v. Clark, 29 F. Supp. 138, 139-40 (W.D. Mo. 1939); Wisniewski v. United States, 47 F.2d 825, 826 (6th Cir. 1931) (dictum). See also United States v. Horton, 86 F. Supp. 92, 97, 98 (W.D. Mich. 1949).

The personal knowledge requirement appears to stem from Carroll v. United States, 267 U.S. 132, 162 (1925). Following Carroll, the Supreme Court has sought to discover some personal knowledge to uphold findings of probable cause, but no case states such evidence as a requirement. See, e.g., Scher v. United States, 305 U.S. 251, 254 (1938); Husty v. United States, supra, at 701; Dumbra v. United States, 268 U.S. 435, 440-41 (1925); Steel v. United States, 267 U.S. 498, 504-05 (1925). But it is questionable whether Carroll actually required some personal knowledge or, if it did, whether the cases on which the Court relied demanded such a holding. See note 56 infra and accompanying text. 
Though both rules require rejection of findings of probable cause based solely on hearsay, ${ }^{12}$ some courts have held to the contrary. ${ }^{13}$

In the recent case of United States v. Costello ${ }^{14}$ the Second Circuit sustained a grand jury's finding of probable cause based solely on hearsay. Costello was indicted for income tax evasion and was proved guilty by the net worth-expenditure method. ${ }^{15} \mathrm{He}$ attacked the indictment on the ground that the grand jury heard only hearsay and sought to show this by proving that the three trial witnesses who appeared before the grand jury were revenue agents whose testimony must have been hearsay. ${ }^{16}$ The court conceded Costello's argument but

12. While in only one case has an indictment been dismissed because it rested solely on hearsay, United States v. Rubin, 218 Fed. 245 (D. Conn. 1914), the federal courts have often stated by way of dictum that this would be grounds for dismissal if proved. See, c.g., United States v. Holmes, 168 F.2d 888, 890 (3d Cir. 1948); Murdick v. United States, 15 F.2d 965,967 (8th Cir. 1926).

Hearsay has been held insufficient to support an arrest or search. E.g., Contee v. United States, 215 F.2d 324, 327 (D.C. Cir. 1954); Rose v. United States, 45 F.2d 459, 464 (Sth Cir. 1930) ; see United States v. Bianco, 189 F.2d 716, 720 (3d Cir. 1951) (dictum).

13. United States v. Costello, 221 F.2d 668, 676-79 (2d Cir. 1955) (grand jury); United States v. Li Fat Tong, 152 F.2d 650 (2d Cir. 1945) (arrest without warrant); United States v. Heitner, 149 F.2d 105 (2d Cir. 1945) (same-alternative holding) ; King v. United States, 1 F.2d 931 (9th Cir. 1924) (search without warrant based on "reliable and positive information") ; United States v. Tolomeo, 52 F. Supp. 737 (W.D. Pa. 1943) (search warrant-alternative holding) ; United States v. Bookbinder, 278 Fed. 216, 218 (E.D. Pa. 1922) (search warrant) ; United States v. Guller, 101 F. Supp. 176, 179 (E.D. Pa. 1951) (dictum -arrest without warrant). See United States v. Gowen, 40 F.2d 593, 596 (2d Cir. 1930), rev'd on other grounds sub nom. Go-Bart Importing Co. v. United States, 282 U.S. 344 (1931). See also Ely, Probable Cause in Connection with Applications for Search Warrants, 13 ST. Lours L. REv. 101, 107-10 (1927).

14. 221 F.2d 668, $677-79$ (2d Cir.), cert. granted, 350 U.S. 819 (1955). Certiorari was limited to the question: "May a defendant be required to stand trial and a conviction be sustained where only hearsay evidence was presented to the grand jury which indicted him?"

15. United States v. Costello, 221 F.2d at 670.

The indictment was returned under Int. Rev. Code of 1939, § 145(b), 52 Stat. 513 (now InT. REv. Cone of 1954, § 7201). The net worth-expenditure method is a means of proving income tax evasion by circumstantial evidence. The government first proves the value of a taxpayer's net worth at the beginning of the tax year under investigation and subtracts this figure from his net worth at the end of the year. The resulting amount (increase in net worth) is added to the taxpayer's nondeductible living expenses for the year. If this total exceeds the taxpayer's reported taxable income plus any discovered nontaxable income, the excess is claimed by the government to be unreported taxable income. See Holland v. United States, 348 U.S. 121, 125 (1954). The government seeks to prove the intent to evade payment of taxes, the second element of the offense, from the accused's conduct, "the likely result of which would be to mislead or conceal." Spies v. United States, 317 U.S. 492, 499 (1943). Such conduct includes, for example, evidence of previous tax evasion activities, improperly kept books, or the absence of records. See Balter, FraUd Under Federal Tax Law \$\$ 194, 214, 215 (2d ed. 1953) ; Avakian, Net Worth Complltations as Proof of Tax Evasion, 10 TAX L. Rev. 431, 447-49 (1955).

16. Brief for Appellant, pp. 41-43, United States v. Costello, 221 F.2d 668 (2d Cir. 1955) ; Brief for Petitioner for Certiorari, pp. 4, 9, Costello v. United States, 350 U.S. 81 y (1955). Costello's initial motion to dismiss the indictment because "there was no law- 
nevertheless held that the hearsay evidence could establish probable cause since it was "rationally persuasive."17 This holding directly rejects the requirement that indictments must rest on some competent evidence, and clearly establishes a rule which the court had implicitly stated in earlier cases validating arrests. ${ }^{18}$

Although Costello does not adequately evaluate the absence at the grand jury of all factors which tend to oppose allowing hearsay alone to establish probable cause, the opinion properly emphasizes the lack of an accused's right of cross-examination at this proceeding. ${ }^{19}$ The need for cross-examination results from recognition that all evidence is unreliable to some extent. ${ }^{20}$ Through cross-examination each party has the opportunity to expose the unreliable portion of his opponent's evidence. ${ }^{21}$ Since cross-examination cannot test the reliability of hearsay, most hearsay evidence is excluded at trial. ${ }^{22}$ But in grand

ful evidence" was made before trial and was denied on the ground that he had not overcome the presumption that the indictment was based on competent evidence. Transcript of Record, p. 84a, United States v. Costello, 119 F. Supp. 159 (S.D.N.Y. 1954). This motion was renewed at the end of the government's case and at the end of the whole case, but was denied both times. Transcript of Record, pp. 1651a, 1782a. The Second Circuit noted that under FED. R. CRns. P. 12(b) (4) Costello could have requested the trial court to defer ruling on the motion to dismiss until trial. He had failed to make this request, however. The court declared that it could possibly refuse to pass on the trial judge's denial of the motions to dismiss since the initial denial before trial was clearly valid on the evidence then available and might be interpreted as settling the issue in the absence of Costello's request that determination of the motion be deferred. But the court refused to dispose of the issue on such a "formal and harsh ground." United States v. Costello, 221 F.2d 668, 677 (2d Cir. 1955).

17. Id. at 676-77. The court could have avoided deciding the issue of whether hearsay alone could support the indictment by holding that the defendant had not offered sufficient proof that all the evidence before the grand jury was incompetent. See, e.g., United States v. Weber, 197 F.2d 237 (2d Cir.), cert. denied, 344 U.S. 834 (1952) ; United States v. Holmes, 168 F.2d 888, 890 (3d Cir. 1948) ; Anderson v. United States, 273 Fed. 20, 29 (Sth Cir. 1921). See also Banks v. United States, 204 F.2d 666 (8th Cir. 1953), remanded, 348 U.S. 905, conviction affirmed, 223 F.2d 884 (8th Cir. 1955).

18. United States v. Li Fat Tong, 152 F.2d 650 (2d Cir. 1945) ; United States v. Heitner, 149 F.2d 105 (2d Cir. 1945) (alternative holding). But none of the cases cited in United States v. Heitner, supra, at $106 \mathrm{n} .1$, directly holds that hearsay alone may establish probable cause for arrest. Both Li Fat Tong and Heitner state that hearsay may establish probable cause because valid arrests do not require the same strict proof as does the issue of guilt, and because the weight to be given the evidence supporting the arrest is for the sound discretion of the court.

19. United States v. Costello, 221 F.2d 668, 678 (2d Cir. 1955). The theory and history of the hearsay rule support the view that the main reason for excluding hearsay at trial is the right of adversary cross-examination. 5 WIGMoRe $\$ \$ 1362,1364$; McCORMICK, EvIIENCE 458 (hereinafter cited as MCCORMICK); Morgan, The Jury and the Exclusionary Rules of Evidence, 4 U. CHI. L. Rev. 247, 253-56 (1937).

20. See 5 Wigarore $\$ \$ 1362,1367$; MCCoRAICK 40.

21. 5 Wigmore 34. Another major purpose of cross-examination is to uncover the "remaining and qualifying circumstances of the subject of testimony" which will often remain hidden on direct examination. Id. at 33 .

22. For a concise statement illustrating how hearsay is not subject to the usual tests of reliability, see Morgan, Hearsay Dangers and the Application of the Hearsay Concept, 62 Harv. L. REv. 177-79 (1948). 
jury proceedings there is no right of adversary cross-examination to test even eye-witness evidence. Therefore, as Costello reasons, in the absence of the principal means of eliminating unreliable evidence, hearsay becomes as valid a basis for indictment as competent evidence. ${ }^{23}$ But in reality cross-examination is not entirely absent at grand jury proceedings since the jurors themselves may examine witnesses on an accused's behalf. ${ }^{24}$ Admittedly, the value of this questioning to test reliability would be lost by a rule allowing hearsay indictments. Such cross-examination is, however, presumably less effective than that of a defendant's counsel at trial, ${ }^{25}$ and would probably provide negligible protection to an accused in a proceeding which is often, as a practical matter, completely subject to the prosecutor's control. ${ }^{26}$ The absence of substantial cross-examination indicates that a lower standard of reliability is permissible at a grand jury proceeding than is required at trial. ${ }^{27}$ Evaluation of the Second Circuit rule, therefore, depends on the extent to which the use of hearsay eliminates factors other than cross-examination that insure reliability, and thereby further reduces the accused's protection. These factors are demeanor evidence, oath and the reduced risk of inaccurate transmission inherent in direct testimony. ${ }^{28}$

While the benefits of firsthand evidence other than the opportunity for crossexamination are probably not significant tests of reliability, they cannot be discounted as easily as the Second Circuit assumes. Costello admits that there is "some warrant of reliability" in the oath and demeanor evidence, but argues that if these factors were valid tests of reliability, all hearsay would be inadmissible at trial. ${ }^{29}$ The decision then cites exceptions to the hearsay rule to disprove this argument. ${ }^{30}$ The court asserts that necessity is the basis for these exceptions. $^{31}$ Actually, the exceptions are permitted largely because of the guaranty of reliability which the surrounding circumstances impart to the de-

23. United States v. Costello, 221 F.2d 668, 678 (2d Cir. 1955).

24. This power may be inferred from the language trial judges use in charges to the grand jury. E.g., Charge to the Grand Jury, 9 F.R.D. 649 (1949); id., 4 F.R.D. 243, 248 (1945).

25. Cf. 5 WIGMORE $29 \mathrm{n} .2$, commenting on Continental practice, where examination of witnesses is conducted by or through the judge "by repetition of questions, and in practice cross-examination is so casual or so feeble as to be a negligible quantity."

For an example of unusually intensive questioning by a grand juror, see United States v. Remington, 208 F.2d 567, 572 (2d Cir. 1953) (dissenting opinion). In Remington, however, the witness was seeking to withhold information necessary for the government's case.

26. See, e.g., Natronar Conmisston on Law Observance and Enforcenient, RePORT ON PROSECUTTON 36 (1931) : "It is unusual for grand juries to go into a thorough, independent investigation of any ordinary case unless the prosecution is willing."

27. This is already evident from the less stringent rules of evidence permitted by the present rule. See grand jury cases at notes 9,10 supra and accompanying text.

28. See MCCORMICK 457-58; 5 WigMORE 7, 8, 125.

29. United States v. Costello, 221 F.2d 668, 678 (2d Cir. 1955).

30. Id. at 677 .

31. Ibid. The court emphasizes "the inaccessability of any better evidence." 
clarant's statements. ${ }^{32}$ Such hearsay exceptions as dying declarations, spontaneous exclamations and business records are illustrative. ${ }^{33}$ In each example some guaranty of the hearsay declarant's trustworthiness exists which replaces the need for other tests of reliability. Since most hearsay exceptions are justified on independent grounds of reliability, their existence does not, as the court contends, indicate that demeanor and the oath lack validity as factors in determining the reliability of evidence.

Measuring the intrinsic value of demeanor evidence, the oath and the risk of inaccurate transmission must be largely a subjective process. Whatever merit demeanor evidence has is sharply reduced at the grand jury because of the absence of cross-examination. ${ }^{34}$ Physical manifestations of lying or uncertainty are most likely to develop only when a witness is subjected to adversary questioning. Perhaps the vigor or vagueness of a witness's direct testimony is some indication of reliability, but the amount is small compared with demeanor evidence disclosed on cross-examination. The oath in no way affects the degree of unreliability attributable to innocent misstatement, ${ }^{35}$ and whether it prevents lying is doubtful. ${ }^{30}$ However, sworn testimony does render a witness liable for perjury, and for this reason the oath will tend to encourage honesty. The risk of inaccurate transmission includes the risks of faulty perception and memory to which even eyewitness testimony is subject. ${ }^{37}$ With hearsay these

32. See Hoffman v. Palmer, 129 F.2d 976, 980-82 (2d Cir. 1942), aff'd, 318 U.S. 109 (1943); 5 WIGMORE $\$ \S 1421-23$; Leflar, Theory of Evidential Admissibility-Statements Made Out of Court, 2 Ark. L. Rev. 26, 37 (1947).

33. See 5 WIGMORE $\$ 1438$ at 231 (with a dying declaration, "the situation supplies a circumstantial probability of accuracy equivalent to that of the tests of oath and crossexamination"); 6 id. $\$ \$ 1747,1749$ (spontaneous exclamations); 5 id. $\$ 1522$ (business records). See also Hoffman v. Palmer, 318 U.S. 109, 113 (1943) (the rule admitting evidence contained in business records was "designed to facilitate admission of records which experience has shown to be quite trustworthy") ; MCCORMIICK 596-97.

34. Wigmore indicates that a witness's presence before the tribunal is interwoven with an accused's right to be confronted by the witnesses against him. The main purpose of confrontation is to enable cross-examination to be carried on. While demeanor is recognized as having independent value of its own, it is described as a "secondary advantage" compared to the right of cross-examination. 3 WIGMORE $\$ 946 ; 5$ id. $\$ \$ 1395,1399$.

35. The purpose of the oath is to to put the witness "in a frame of mind calculated to speak only the truth as he saw it" by appealing either to the threat of divine punishment or to the witness's own conscience. 6 WIGMORE $\$ 1816$. In either case, the appeal is directed toward a restriction of deliberate falsification.

36. "The deliberate expression by a witness of his purpose to tell the truth by a method which is binding on his conscience probably still operates as some stimulus to tell the truth; but fear of punishment by supernatural forces for violation of an oath is generally regarded as virtually non-existent; and the threat of prosecution for perjury has little effect." Morgan, supra note 22 , at 186 .

For a critical study of the history and purpose of the oath, see White, Oaths in Judicial Procecdings and Their Effect Upon the Competency of Witnesses, 51 AMr. L. REg. (n.s.) 373 (1903).

37. See Gardner, The Perception and Memory of Witnesses, 18 CoRnell L.Q. 391 (1933); Hutchins \& Slesinger, Some Observations on the Law of Evidence-IIemory, 41 HARv. L. REv. 860,867 (1928). 
risks are multiplied by the number of persons through whom the eyewitness evidence is transmitted to the triers of fact. But the increase in these risks is introduced whenever oral hearsay is admitted at trial as exceptions to the hearsay rule. ${ }^{38}$ Unlike the loss of demeanor evidence and the oath, added risks of inaccurate transmission are not remedied by the circumstances surrounding the declarant's statements which tend to indicate his trustworthiness. ${ }^{39}$ Since trial jurors must evaluate these added risks when considering hearsay exceptions, grand jurors can similarly evaluate them for all hearsay.

Courts have indicated that the combined value of demeanor evidence, the oath and the reduced risk of inaccurate transmission, available with eyewitness testimony, is not a sufficient guaranty of reliability to justify using such evidence when cross-examination is lacking. This attitude is revealed in cases where a witness has completed his direct testimony, but for some reason is not cross-examined. The direct testimony is generally excluded unless the party entitled to cross-examine has in some way forfeited the opportunity. ${ }^{40}$ Even the few cases admitting such direct testimony place no emphasis on the importance of the oath or demeanor evidence. ${ }^{41}$

Practical operation of the present rule requiring the grand jury to hear some competent evidence almost entirely eliminates whatever value demeanor evidence, oath and firsthand perception may provide as tests of reliability. The existing rule permits the grand jury to receive unlimited amounts of hearsay as long as some competent evidence is also introduced. ${ }^{2} 2$ The rule in effect permits hearsay to establish probable cause since, as courts have often stated, only a scintilla of competent evidence is required. ${ }^{43}$ This interpretation rests

38. The increased risk of inaccurate transmission which results from use of hearsay is absent where the hearsay is written. But even written hearsay is generally excluded at trial unless it can be brought within one of the exceptions to the hearsay rule. See 5 WIGMORE $\$ 1363(1)$.

39. In fact, the risk of inaccurate transmission may be increased in some exceptions to the hearsay rule, such as spontaneous exclamations and dying declarations, just because of the hearsay declarant's excitement or shock at the time of declaration. See Hutchins \& Slesinger, Some Observations on the Law of Evidence-Spontaneons Exclamations, 28 Colun. I. REv. 432, 437-38 (1928).

40. See, e.g., Nehring v. Smith, 243 Iowa 225 , 49 N.W.2d 831. (1951) ; Best v. Tavenner, 189 Ore. 46, 218 P.2d 471 (1950). See also 5 Wrgmone \$ 1390; McComaick 41-42; MCKelvey, Evmence 584-85 (1944) ; Morgan, supra note 22, at 184.

41. See, e.g., Scott v. McCann, 76 Md. 47, 24 Atl. 536 (1892). ("By the act of God the plaintiff was deprived of a privilege [of cross-examination] which we think would have been productive of no benefit to him."); Stephan v. United States, 133 F.2d 87, 97 (6th Cir.), cert. denied, 318 U.S. 781 (1943). ("The refusal of [the witness] . . to answer these few questions was not objected to, and fewer still were of any relevance to appellant's guilt."). But cf. Notes, 35 Calif. L. Rev. 299, 301 (1947), 27 Colun. L. Rev. 327 (1927).

42. See note 10 supra and accompanying text.

43. See, e.g., United States v. Costello, 221 F.2d 668, 678 (2d Cir. 1955); Olmstead v. United States, 19 F.2d 842, 845 (9th Cir. 1927), aff'd on other grounds, 277 U.S. 438 (1928) ; Murdick v. United States, 15 F.2d 965, 967 (8th Cir. 1926), cert. denied sub nom. Clarey v. United States, 274 U.S. 752 (1927) ; cf. United States v. Morse, 292 Fed. 273, 277-78 (S.D.N.Y. 1922). See Note, 62 Harv. L. Rev. 111, 113 (1948). 
an accused's protection on a requirement whose effectiveness is as small as the quantity of competent evidence it demands. Admittedly, some courts have verbalized the present rule as requiring that the competent evidence itself be suffcient to establish probable cause. ${ }^{44}$ But in reviewing grand jury proceedings, federal courts refuse to weigh the sufficiency of the evidence, ${ }^{45}$ and will dismiss an indictment only when an accused has proved that the grand jury heard no competent evidence. ${ }^{46}$ Since any amount of competent evidence will sustain an indictment, the verbal requirement of enough competent evidence to establish probable cause becomes in essence the scintilla standard. Furthermore, proving absence of any competent evidence is a virtually hopeless task. An accused must overcome the presumption that the grand jury proceedings were proper. ${ }^{47}$ Adoption of the Second Circuit rule, therefore, reduces an accused's protection from unreasonable prosecution only a negligible amount below the present standard.

Even if courts would adopt and enforce a rule requiring competent evidence alone to establish probable cause, hearsay should still be considered competent before grand juries. A test of competency at the grand jury level may properly be satisfied by a lower standard of reliability than is required at trial. As has been indicated, criminal procedure already approves a lowered standard at the grand jury stage in that cross-examination, the main device for testing the reliability of all evidence, is not made available to the accused. ${ }^{48}$ The reason for such approval is that the standard of the trial rules is unnecessary in a proceeding where the adverse consequence to an accused, the risk of trial, is less serious than a determination of guilt. ${ }^{49}$ Logic may suggest, however, that insofar as the trial rules of evidence are a desirable means of determining the truth, they should apply in all proceedings regardless of the varying amounts of evidence required to establish different findings. But since this logic has not forced the introduction of cross-examination in grand jury proceedings, it would

44. See, e.g., United States v. Smyth, 104 F. Supp. 283, 300 (N.D. Calif. 1952) ; United States v. Brumfield, 85 F. Supp. 696, 704-05 (W.D. La. 1949); United States v. Bolles, 209 Fed. 682, 684 (W.D. Mo. 1913). See also United States v. Remington, 208 F.2d 567, 573-74 (2d Cir. 1953) (dissenting opinion), cert. dented, 347 U.S. 913 (1954).

45. E.g., United States v. Cohen, 113 F. Supp. 955 (S.D.N.Y. 1953) ; United States v. Frontier Asthma Co., 69 F. Supp. 994, 999 (S.D.N.Y. 1947) ; United States v. Cobban, 127 Fed. 713, 721 (C.C.D. Mont. 1904) ; cf. Carrado v. United States, 210 F.2d 712, 717-18 (D.C. Cir. 1953).

46. Brady v. United States, 24 F.2d 405, 408 (8th Cir. 1928); Nanfito v. United States, 20 F.2d 376, 378 (8th Cir. 1927).

47. See, e.g., Cox v. Vaught, 52 F.2d 562 (10th Cir. 1931); United States v. Wolrich, 127 F. Supp. 215 (S.D.N.Y. 1955). See also 4 Barron, Federal Practice and Procedure $\$ 1897$ (rules ed. 1951).

This presumption derives from the secrecy of grand jury proceedings. See United States v. Johnson, 319 U.S. 503, 513 (1943).

48. See text at notes 8-9, 19-23 supra.

49. See Brinegar v. United States, 338 U.S. 160, 175 (1949): "The standard of proof is . . . correlative to what must be proved." 
seem even less to demand the continued presence of tests of reliability whose combined value is apparently inferior to that of cross-examination alone.

Allowing indictments to be based on hearsay alone is of considerable importance in net worth cases like Costello. In these prosecutions, as in all criminal tax evasion cases, the offense is composed of two elements: intent to evade taxes and improper reporting of taxable income.50 Probable cause of all elements of an offense must be shown at the grand jury. ${ }^{51}$ Unless the government has an admission from an accused or some other competent evidence of improper reporting of income, the hearsay evidence of the revenue agents will not suffice to show probable cause on this issue under the present rule requiring some competent evidence. ${ }^{52}$ The government would then be required to present to the grand jury all its firsthand witnesses on this element of the offense, since the theory of prosecution in these cases requires proof of the taxpayer's net worth and his nondeductible expenditures, issues which could not readily be shown by any few witnesses. ${ }^{53}$ Admittedly, in cases where even a small amount of competent evidence could indicate probable cause, the argument for permitting hearsay indictments rests on convenience of prosecution. Ordinarily convenience is considered of minor importance in criminal law when compared with an accused's substantial rights. But if convenience is achieved with no more than a negligible reduction in an accused's protection, it should be considered a decisive factor in the administration of justice.

If hearsay alone may constitute a valid basis for indictments, the question arises whether it should also be sufficient to establish probable cause at preliminary proceedings before a commissioner. At first glance, such a rule is even more appealing in these proceedings than at the grand jury because an accused is exposed to a lesser risk than indictment. Noreover, the Supreme Court has emphasized the desirability of a "practical, nontechnical" approach in formulating evidentiary standards in this area. ${ }^{54}$ It is true that the Court has invariably based its determinations of probable cause for arrests and searches

50. Avakian, Net Worth Method of Establishing Fraud, N.Y.U. 11TH INST. ON FED. TAx. 707, 719 (1953).

51. See Brady v. United States, 24 F.2d 405, 408 (Sth Cir. 1928).

52. But if the offense were considered as a whole, conceivably the government could satisfy the present rule's requirement of some competent evidence by producing part of the evidence it intends to use at trial to prove the frist element of the offense, intent to evade. It would not be difficult to offer such evidence before the grand jury. See BALTER, Fraun UNDER FedERAL TAX LAw \$ 194 (2d ed. 1953).

53. See note 15 supra. In Costello, for example, the three revenue agents who appearcd before the grand jury had circularized banks to learn where the defendant had accounts, supervised preparation of charts illustrating defendant's expenditures, and prepared reconstructed tax returns indicating the government's claim of true income. Transcript of Record, pp. 1383a, 1398a, 1428a, 1588a-89a, United States v. Costello, 119 F. Supp. 159 (S.D.N.Y. 1954). Proving these items by competent evidence would have required the testimony of many business men and more revenue agents, or at least the introduction of voluminous documents which satisfied the business records exception to the hearsay rule.

54. See Brinegar v. United States, 338 U.S. 160, 176 (1949). 
on both hearsay and personal knowledge. ${ }^{55}$ But since there was some personal knowledge in each case, the Court has not had occasion to decide whether hearsay alone would suffice. Indeed, the state cases on which the Court relied to develop its definition of probable cause declared that hearsay alone could support this finding. ${ }^{56}$ Nevertheless, lower federal courts interpreted the Supreme Court decisions which relied in part on personal knowledge as requiring this type of evidence for a finding of probable cause, though this conclusion was not logically compelled.57

Clearly, most reasons for permitting indictments to be based on hearsay alone support a similar rule at commissioner's proceedings. Like the grand jury hearing, commissioner's proceedings for the issuance of warrants are $e x$ parte, and no right of cross-examination is afforded. At the hearing after arrest, on the other hand, this right is available to an accused, ${ }^{58}$ and it may therefore be argued that the Costello rule should not be adopted for this proceeding. But whatever protection an accused might gain from the use of crossexamination in the hearing after arrest could be eliminated at the government's discretion through its power to by-pass the commissioner and initiate prosecution by grand jury indictment. ${ }^{59}$ A second argument against applying the Costello rule is that in proceedings initiated by police officials, who may be overly eager to arrest or search, no change in evidentiary rules should be allowed which might conceivably reduce an accused's protection. ${ }^{60}$ However, use of hearsay will not prejudice an accused so long as the commissioner enforces the Costello standard of "rationally persuasive" evidence. In the final analysis, whether or not the Costello rule should be applied at commissioner's

55. See Supreme Court cases cited in note 11 supra.

56. The Court's definition of probable cause as "reasonable ground for belief of guilt," Carroll v. United States, 267 U.S. 132, 161 (1925), was drawn from McCarthy v. De Armit, $99 \mathrm{~Pa} .63$ (18S1). De Armit was an action for false imprisonment in which the evidence supporting the plaintiff's arrest was apparently hearsay. The court stated: "Representations of others may be an adequate foundation for [probable cause] ... especially if made by those who have had opportunities for knowledge, or who have made investigation." Id. at 69 . The De Armit court in turn cited Smith v. Ege, $52 \mathrm{~Pa}$. (2 P.F.S.) 419,422 (1865), an action for malicious prosecution in which the court declared: "It can make no difference what induces the belief, if it be reasonably sufficient."

In Rohan v. Swain, 59 Mass. 281, 284 (1850), another case cited in Carroll to support the definition of probable cause, English authorities which allowed arrests to be made on hearsay were noted approvingly. Commonwealth v. Carey, 66 Mass. (11 Cush.) 246, 251 (1853), also relied on in Carroll, declared that a police officer could arrest without a warrant "if he suspects one on his own knowledge of facts, or on facts communicated to him by others...." (Emphasis added.)

57. See lower court cases cited at note 11 supra, and arrest and search cases cited at note 12 supra.

58. Fed. R. Criar. P. 5(c) ; Manual for United States Commissioners 9 (1948).

59. See note 5 supra and accompanying text.

60. See Brinegar v. United States, 338 U.S. 160, 182 (1949) (dissenting opinion) : "[The Court] ... must remember that the extent of any privilege of search and seizure without warrant which we sustain, the officers interpret and apply themselves and will push to the limit." 
proceedings depends on the adequacy of judicial review. The courts have been more ready to review these proceedings than to probe the action of the grand jury. ${ }^{61}$ Since judicial scrutiny is reasonably certain, whatever dangers may exist in extending the Second Circuit rule to commissioner's proceedings would be minimized. The Costello test should, therefore, become the accepted standard for all preliminary proceedings.

61. The public nature of commissioner's proceedings has been a major factor enabling courts to subject them to broader review at trial or on appeal. Defendants have been in a better position to attack such proceedings for the same reason. And if the cases in which warrants have been quashed as compared with indictments dismissed are any illustration of judicial control, they support the conclusion that the commissioner is subject to much greater court regulation than is the grand jury, at least in the area of evidence to establish probable cause. See, e.g., United States v. Langsdale, 115 F. Supp. 489, $491-92$ (W.D. Mo. 1953), appeal dismissed, 209 F.2d 955 (Sth Cir. 1954). 